\title{
Position of the Regional Representative Board of the Republic of Indonesia in Indonesian Administrative System
}

\author{
Muhammad Hubbul Khair Wasahua \\ Law Study Consentration of Constitutional Law Graduate Program Universitas Muslim Indonesia, \\ Indonesia \\ hubbulkhair@gmail.com
}

\begin{abstract}
The Regional Representative board of the Republic of Indonesia is one of the state institutions mentioned in the 1945 Constitution of the Republic of Indonesia. Although it has high legitimacy, it is not comparable with its authority. The position of the Indonesian Regional Representative Board (DPD RI) does not have authority in the legislative function, although it is limited to submitting and discussing certain draft laws that have been proposed, as well as in terms of supervision which is limited to supervising the implementation of certain laws and discussing and provide consideration of the results of its supervision to the House of Representatives (DPR). The ideal idea to strengthen the position of the Indonesian Regional Representative Board from experts, as well as from the results of the analysis of the author is carried out the fifth amendment to the 1945 Constitution of the Republic of Indonesia, one of which is in terms of its authority so that it is equal to the authority of the House of Representatives, which can participate in deciding the draft law related to its authority following Article 22D of the 1945 Constitution of the Republic of Indonesia. Besides that, so that the Indonesian legislative body can adopt strong bicameralism, unperfect bicameralism.

Keywords: Position Regional Representative board of the Republic of Indonesia Bicameral system, and the rule of law
\end{abstract}

\begin{abstract}
Abstrak. Dewan Perwakilan Daerah Republik Indonesia merupakan salah satu lembaga negara yang disebutkan dalam Undang-Undang Dasar Negara Republik Indonesia Tahun 1945. Meskipun memiliki legitimasi tinggi, namun hal tersebut tidak sebanding dengan kewenangan yang dimilikinya. Kedudukan Dewan Perwakilan Daerah Indonesia (DPD RI) tidak mempunyai wewenang dalam fungsi legislasi, meskipun hanya sebatas mengajukan serta membahas rancangan undang-undang tertentu yang telah diajukan, begitu pun dalam hal pengawasan yang hanya sebatas mengawasi terkait pelaksanaan terhadap undang-undang tertentu dan membahas serta memberikan pertimbangan hasil pengawasannya ke Dewan Perwakilan Rakyat (DPR). Gagasan ideal untuk memperkuat Kedudukan Dewan Perwakilan Daerah Indonesia dari para ahli, maupun dari hasil analisis penulis adalah dilakukan amandemen kelima Undang-Undang Dasar Negara Republik Indonesia Tahun 1945, salah satunya yaitu dari segi kewenangannya agar setara dengan kewenangan Dewan Perwakilan Rakyat, yang dapat ikut memutuskan rancangan undang-undang yang terkait dengan kewenangannya sesuai Pasal 22D Undang-Undang Dasar Negara Republik Indonesia Tahun 1945. Disamping itu juga agar lembaga legislatif Indonesia dapat menganut lembaga perwakilan kuat (strong bicameralism), bukan yang sempurna (perfect bicameralism).
\end{abstract}

Kata kunci: Kedudukan DPD RI, Sistem Bikameral, dan Negara Hukum 


\section{INTRODUCTION}

The government system is generally divided into two main systems, namely the presidential system and the parliamentary system. Outside of the two systems are called "mixed" systems, they can also be quasi presidential or quasi parliamentary. However, some refer to the referendum system, which is a system where the executive body is part of the legislative body, or what is commonly referred to as the legislative worker body. In this system, the legislative body forms a subbody within it as the executor of government duties. Control over the legislature is carried out directly through a referendum (Sulardi, 2012)

The characteristics of constitutional democracy contain the idea that the government in carrying out its duties and functions is regulated in the constitution and written legal rules in force so that the government is not justified to act arbitrarily. The idea of constitutional democracy was formulated by Lord Acton the British historian, he said "Power tends corrupt, but absolute power corrupt absolutely (Manusia yang memiliki kekuasaan cenderung menyalahgunakan kekuasaan, tetapi manusia yang memiliki kekuasaan tak terbatas pasti menyalahgunakaan kekuasaan tak terbatas pula)" (Lord Acton dalam Miriam Budiardjo 2013).

The rule of law state put forward by Frederich Julius Stahl to the state adheres to the Continental European system, namely ownership or sharing of power to guarantee human rights (Sarja, 2016)

Indonesia as a country that adheres to Pancasila democracy is based on popular sovereignty supported by crystallized norms in the constitution. The sovereignty of the people and the sovereignty of the law are an inseparable unity and are a major component of being able to provide welfare for its people. Understanding the sovereignty of the people adopted by this country means that the real power is in the hands of the people. That power must be realized from the people, by the people and for the people (Jimly Asshiddiqie, 2006). The bicameral system adopted by Indonesia is the two-chamber system within the legislative body. In the two-room system consists of the House of Representatives (DPR) and the Regional Representative Board (DPD). The presence of the two-state institutions is to be able to carry out supervision of the implementation of the law, as well as participate in the process of making laws (checks and balances) (Indonesian MPR Study Board, 2017).

The theory of the separation of powers echoed by John Locke consists of three branches of power, the first is the legislative power that has to make laws, the second is the executive power which must implement the law, then the third is the federative power which has the task to conduct international relations with other countries. Unlike the 
concept of separation of powers proposed by Montesquieu which consists of legislative power, executive power, and judicative power.

Indonesia as a modern democracy adopted a presidential government system. The bicameral system adopted by Indonesia has two rooms. The doctrine of the bicameral system comes from the classical theories of Aristotle and Polybius who argue that combining democracy and oligarchy is good governance. From this theory then created birth to a two-chamber legislative idea termed by Jeremy Bentham (Robert L. Madex in Saldi Isra, 2010).

Implicitly, the functions and authority of the Regional Representatives Board of the Republic of Indonesia (DPD RI) are regulated in the 1945 Constitution of the Republic of Indonesia in Chapter VIIA Article 22D, which reads Paragraph (1) regions, central and regional relations, formation and expansion and merging of regions, management of natural resources and other economic resources, and financial balance between the centre and the regions ", Paragraph (2)" The Regional Representative Board shall also discuss the draft law relating to autonomy. area; central and regional relations; formation, expansion, and merging of regions; management of natural resources and other economic resources, as well as central and regional financial balance; and consider the House of Representatives on the draft laws relating to tax, education and religion ",
Paragraph (3)" The Regional Representative Board can supervise the implementation of laws concerning: regional autonomy, the formation, expansion, and incorporation of regional, central and regional relations, management of natural resources and other economic resources, implementation of the state revenue and expenditure budget, taxes, education, and religion and submit the results of their supervision to the House of Representatives as a material for consideration to be followed up ", Paragraph (4) "Members of the Regional Representative Council may be dismissed from their positions, the terms and procedures of which are regulated by law" (Republic of Indonesia, 1945).

Furthermore, related to the authority and duties are also regulated in the provisions of Article 249 of the Law of the Republic of Indonesia Number 2 of 2018 concerning the second amendment to Law Number 17 of 2014 concerning the People's Consultative Assembly, the House of Representatives, the Regional Representative Board, and the House of Representatives Regions that read Paragraph (1) DPD has the authority and duties:

1. submit a draft law relating to regional autonomy, central and regional relations, the formation and expansion and merging of regions, management of natural resources and other economic resources, and relating to the balance of central and regional finances to the DPR; 
2. participate in discussing the draft law relating to the matter referred to in letter a;

3. compile and submit a list of inventory issues of draft laws originating from the Parliament or the President relating to the matter referred to in letter a;

4. give consideration to the DPR for the draft law on the state budget and the draft law relating to tax, education and religion;

5. can supervise the implementation of laws concerning regional autonomy, the formation, expansion, and merging of regions, central and regional relations, management of natural resources, and other economic resources, implementation of the National Budget, taxes, education, and religion.

6. convey the results of supervision of the implementation of the law on regional autonomy, the formation, expansion, and merging of regions, central and regional relations, management of natural resources and other economic resources, implementation of the state budget, tax, education, and religion law to DPR as material for consideration to be followed up;

7. accepting the results of audits of state finances from the BPK as material for making deliberations to the Parliament regarding the draft law relating to the APBN;

8. give consideration to the DPR in the selection of BPK members;
9. compiling national legislation programs relating to regional autonomy, central and regional relations, the formation and expansion and merging of regions, management of natural resources and other economic resources, as well as those related to central and regional financial balance; and

10.monitoring and evaluating the draft regional regulations and regional regulations. "

Paragraph (2) In carrying out supervisory duties as referred to in paragraph (1) letter e, DPD members may hold meetings with the regional government, DPRD, and elements of the community in their constituency. "(the Republic of Indonesia, 2018)

The authority possessed by the DPD in the Indonesian constitution only has the authority to initiate legislative initiation and discussion of the law (law-making process), Likewise with the supervisory function possessed by the DPD, it is only oriented towards oversight of policies (Jimly Asshiddiqie, 2019). So, it is very clear the role of the DPD in the legislative process, does not have a full role to be able to carry out functions and authorities that can regulate central and regional relations.

Representative institutions owned by Indonesia consist of two chambers (bicameral), namely the DPR and DPD. However, according to several writers and 
reviewers of Indonesian constitutional law, after the amendment to the 1945 Constitution of the Republic of Indonesia, placing the MPR as a separate room, therefore it can be said to have three rooms (tricameral). The reason he said the MPR as the third chamber was because the MPR was a separate body whose members came from the DPR and DPD, so that in the legislation process it had its own discussion, and made a decision on the legislation program that had been discussed in each room (Bagir Manan in Saldi Isra). Unlike the case in the Senate in the United States which has a strong oversight function, so that it can balance the power of The House of Representative whose members come from political parties (Saldi Isra).

The DPD itself has many draft products that could have been legalized in the legislation process, but this cannot be followed up because it is limited by the 1945 Constitution of the Republic of Indonesia and the MD3 Law, so that the initiative undertaken by the DPD is merely wishful thinking. Whereas the purpose of establishing the DPD is to be able to accommodate regional interests and maintain national integrity. Therefore, the group and regional delegates were replaced by the DPD based on the results of the third amendment of the 1945 NRI to avoid executive authoritarianism by controlling the MPR and the DPR (Gabriel Talawe, 2018). Inequality between the DPD and the DPR in the legislative process in history has been an attempt to propose the DPD to reject and approve a bill that has been approved by the DPR, but the proposal was rejected by the DPR and from the community, so the proposal was not followed up (Sulardi).

Thus the only endeavour of the DPD to be able to strengthen its legitimacy to be able to get full authority in the legislation process is to amend the 1945 Constitution of the Republic of Indonesia for the fifth time. At that moment, DPD members must issue opinions and considerations that can provide space to participate in deciding the legislation program that has been designed so far. However, it would be better if the DPD continues to perform its functions and authorities properly, because the membership of the DPD is purely directly elected by the people, and that is more value that is owned because it can be in direct contact with the community.

\section{RESEARCH METHODS}

This research used normative research, which was a type of research that analyzed and examined the provisions of a statute and other written sources, such as books, journals, articles, dictionaries, magazines, newspapers. In this study, the composer in the process used secondary data sources with primary legal material which includes the principles of law, the 1945 Constitution, related laws. Then the secondary legal material in the form of legal textbooks 
relating to the title of this study. As well as tertiary legal materials namely legal dictionaries, legal journals, and encyclopedias.

The technique of collecting legal material through the identification of data, namely by gathering some literature then sorting out and separating the data to be discussed. Data editing was an examination of research data that aims to find out the relevance (relationship) and validity of the data that was described in finding answers to the main problems. To analyze the data, the composer used descriptive analysis, which explained and gave legal meaning to the functions and authorities of the Regional Representative Board of the Republic of Indonesia in the Indonesian constitutional system after the amendment to the 1945 Constitution of the Republic of Indonesia.

\section{DISCUSSION}

\section{The role of the Regional Representative Board of the Republic of Indonesia}

\section{A bill submission}

The authority of the DPD contained in the 1945 Constitution of the Republic of Indonesia Article 22D paragraph (1), the initial process begins with a written submission by the leader of the DPD to the leader of the DPR and must be included with an academic text. This proposal was then conveyed by the DPR Leadership to the DPR's equipment which specifically handles the field of legislation to harmonize, round up and consolidate the bill.
The House of Representatives' implements will then carry out the process of harmonizing, rounding, and consolidating the bill by inviting the DPD equipment which has a duty in the field of the draft law to discuss it. Furthermore, the equipment submits a written report on the results of harmonization (in the previous stage) to the leadership of the House of Representatives to be subsequently announced at the plenary meeting (Hukum, 2011)

Stipulating the bill on the initiative of the DPD is carried out by the Committee / Committee of the draft law by submitting the proposed document of a harmonized draft to the Deliberation Committee to be scheduled in the plenary session. After that, the committee/committee submits an explanation of the proposed draft law and a list of working team members from the committee and the draft law committee at the plenary session to decide. After the initiator submits his explanation, the decision in the plenary session can be accepted without change; accepted with changes; or rejected. If accepted with amendments, the DPD assigns the draft committee/committee to discuss and refine the proposed draft law,then,it is submitted to the chairman (Regulation of the Regional Representative Board of the Republic of Indonesia, 2014)

Prolegnas can be submitted by the DPD RI with provisions to deal with extraordinary problems, or natural conflicts; Or others such as ensuring the existence of national urgency 
or drafting a law that can be accessed together by the DPR's special equipment that specifically installs the field of legislation and ministers who manage affairs in the field of law. Using this law, it can be submitted by the public, members of the DPD, committees, legislators' drafting committees, or by incorporating equipment for the deliberative committee.

After that the proposal was submitted to the leadership of the deliberations with attachments in the form of background and purpose of the preparation; goals to be realized; range and direction of arrangement; compliance with the duties and authority of the DPD; and list of proposers' names and signatures. The deliberative committee after receiving the proposal then determines the competencies/joints of the competent fittings to follow up. Follow-up is done by the fittings/joints of fittings by examining whether the proposal of the bill has fulfilled the stipulated provisions. If the draft law meets the existing provisions, the leader of the equipment/joint of the equipment submits the proposal to the deliberative committee. Deliberation Committee submits its proposal in the next plenary session to make a decision. In the next plenary session, the initiator delivered an explanation related to the proposal. Decisions in the plenary session can be either accepted or rejected. If the proposed bill outside the Prolegnas is rejected, then the proposal cannot be submitted again. However, if the plenary session accepts the proposal, the deliberative committee appoints a legislative committee/committee to prepare and process the draft law as regulated in the DPD RI code of conduct (Regulation of the Regional Representative Council of the Republic of Indonesia, 2014).

The discussion of the draft law proposed by the DPD is discussed by the equipment established by the DPD together with the DPR and ministerial equipment which will represent the President in the first-level talks. The combination of the fittings gives the task team a task to arrange an introduction to the deliberations in the discussion; prepare justifications and arguments in response to a list of inventory problems and questions from the Parliament and the President; follow discussions in the DPR continuously with at least five people who can take turns with each other; arranging mini opinions in level I talk; co-sign the approval of the draft law at the end of the first-level talks including if there is a decision making with the most votes (Regulation of the Regional Representative Board of the Republic of Indonesia, 2014)

The implementation of the work team discussion can adjust attitudes to the dynamics of political development, especially in the event of a mismatch between the concepts proposed by the DPD and the opinions of the government and/or the DPR and report them to the leader of the DPD through the leaders of the legislative committee. The submission of a 
mini opinion was delivered at the end of the first-level talks by the DPD, the DPR, and the President (Regulation of the Regional Representative Board of the Republic of Indonesia, 2014). Discussions on the bill are carried out with work meetings, work agency meetings, drafting teams and / or synchronization team meetings. In the mini opinion, the discussion can be carried out with other mechanisms as long as agreed by the meeting leader and meeting participants (Regulation of the Regional Representative Board of the Republic of Indonesia, 2014)

The national legislation program proposed by the DPR or the President can be followed by the DPD in the discussion by first submitting the draft law through the leadership of the DPD. After being accepted by the leadership, competent equipment must be immediately delivered to formulate views. The material of the proposed bill must be submitted to the deliberative committee to be able to discuss together. The equipment that has been assigned to submit the DPD draft view to the deliberative committee to be scheduled and decided in a plenary session accompanied by a list of names of work team members who will represent the DPD in discussions with the DPR and the Government. In the event that a bill from the DPR or the President based on a fiveyear national legislation program and outside the national legislation program is received by the leadership, immediately deliver it in the next plenary session to assign a tool that will discuss the draft law in question. If the plenary session cannot be held within three days of receipt of the draft law from the DPR or the President, the deliberative committee can decide on the completeness of the instrument to discuss the draft law. After that, the draft law is submitted to DPD Members by the Secretariat General to immediately provide input to the designated equipment (Regulation of the Regional Representative Council of the Republic of Indonesia, 2014)

The authority contained in Regulation Number 1 of 2014 concerning the DPD RI Code of Conduct contains formal rules which are limited to submitting, discussing, and then only accepting the results from the DPD initiative. This makes DPD unable to do much of the region's interest and does not know what the performance can be responsible to the regions which they represent

\section{Supervision}

The Regional Representative Council $(D P D)$ in carrying out its oversight function is regulated in Article 22D paragraph (3) of the 1945 Constitution of the Republic of Indonesia. The supervision of the implementation of these laws and regulations is carried out by Members and Committees. Supervision is carried out in the form of implementation of certain laws and regulations implementing certain laws. Then supervision of the implementation of the law is reported at the beginning of the trial period. The preparation of the results of supervision of the 
implementation of the law and the implementation of its implementing regulations are reported in a plenary session (Regulation of the Regional Representative Council of the Republic of Indonesia, 2014)

The Regional Representative Council $(D P D)$ can also carry out supervision by discussing the results of the BPK inspection. The initial process is that the DPD receives the results of a state financial audit submitted by the leaders of Indonesian Supreme Audit Institution (BPK) to the DPD leader in a plenary session specifically held for this purpose. Concerning the results of the state financial audit, the DPD gives the task to Committee IV to discuss the central government financial statements and the results of the BPK semester examination related to the performance of the audited entity, and the Public Accountability Agency which is tasked with following up on the BPK semester examination results related to findings that indicate a state loss. entity examined Both can coordinate (Regulation of the Regional Representative Board of the Republic of Indonesia, 2014).

Committee IV prepares a follow-up to the results of the BPK examination and reports it to the plenary session to be determined as a DPD decision. The decision of the session was submitted in writing by the leadership of the DPD to the leadership of the DPR. With regard to BPK's findings which are considered detrimental to state finances, the plenary session assigns the Public Accountability Board to carry out a further review as mentioned in Article 102 paragraph (1) of DPD RI Regulation No. 1 of 2014 concerning Standing Orders. Then the results of the review are submitted to the plenary session to be determined and can then be forwarded to the Corruption Eradication Commission. Bada Public Accountability in preparing the followup to the results of the BPK examination in the form of, first, input to Committee IV for consideration to be presented at the plenary session; second, follow-up materials to minimize state losses; third, recommendations to relevant institutions for legal settlement (Regulation of the Regional Representative Council of the Republic of Indonesia, 2014). Examination and reports to the plenary session to be determined as a DPD decision. The decision of the session is conveyed by the leaders of the DPD to the leader of the DPR. With regard to BPK's findings which discuss state finances, the plenary session assigns to the Public Accountability Board to carry out further reviews to receive approval in Article 102 paragraph (1) of DPD RI Regulation No. 1 of 2014 concerning Standing Orders. Then the results of the review are submitted to the plenary session to be determined and can then be forwarded to the Corruption Eradication Commission. The Public Accountability Board in preparing the follow-up to the results of the BPK audit consists of, first, input to Committee IV for consideration that will be 
submitted at the plenary session; second, follow-up material to discuss state losses; ", Recommendations for related institutions to be approved by law (Regulation of the Regional Representative Council of the Republic of Indonesia, 2014).

The supervisory function of the Regional Representative Council itself based on existing regulations can only discuss the results of supervision and request for testing of the implementing regulations. Related to the results of the BPK examination, the results of the discussion are to provide recommendations

Ideal Idea on the Position of the Regional Representatives of the Republic of Indonesia

The regional representative board representation in the Indonesian parliament must be understood because: first, sociologically the community ties with the province are far stronger than the districts; second, it is technically much easier because there is a clear division of administrative territory; third, provincial-based elections are more representative of all regions compared to regency bases, given the number of districts in Java is not balanced with regions outside Java (Fajlurrahman Jurdi, 2019)

As one of the state institutions formed after the 1998 reform, the regional representative board (DPD) must become a chamber in the legislative body that can absorb the aspirations of the people in the regions.
Besides, the presence of the DPD can reinforce the two-room system (bicameral system) at representative institutions in Indonesia. However, the authority possessed by the DPD is not the same as that of the DPR. According to M. Solly Lubis, there are three parliamentary rights in the field of legislation, namely initiative rights, amendment rights, and budget (budgeting) rights (M. Solly Lubis, 1975). Of the three rights, the DPD only has the right to initiative, namely the right to be able to submit and discuss the draft law relating to its authority, without participating in approving the proposed legislation. In the field of supervision, there are also three parliamentary rights in conducting oversight, namely the right of interpellation, the right of petition and the right of inquiry (Constitution of the Republic of Indonesia, 1945)

Other inequality can be seen from the limitation of the regional representative board (DPD) members who only have four people in each province in Indonesia. The article provides substantial electoral injustice because provinces that are densely populated and less populated provinces have an equal share of seats for DPD members. As a result of the electoral injustice, the DPD seats in Java which are famous for being densely populated have very high prices compared to the DPD seats that are outside Java. The opinion related to the representation of the DPD is that it is not necessary to distinguish the number of representation in the legislature. This opinion 
has ignored the fact that those who elect DPD members are people who have the right to vote. To be able to overcome this electoral injustice, it is necessary to make rules such as making intervals of the population in each province directly proportional to the number of representation in the DPD. One example is if the population of each province is under 1 million, the political representation is only four people, then if the population is 1 million to 5 million, then the total political representation is eight people, and so on (Bambang Eka Widodo, 2013)

DPD in carrying out its functions has the authority to propose draft laws relating to regional autonomy, central and regional relations, the formation and expansion and merging of regions, management of natural resources and other economic resources, as well as central and regional financial balances, and those related with the balance of central and regional finances. Beyond his authority, the DPD once had a proposal on strengthening independent state institutions. His proposal relates to the tidying up of state commissions in Indonesia. At the core of his idea, the DPD gives three considerations, first, to strengthen the position of an independent state institution which has become a reality of the state administration regarding its presence, and made a separate chapter entitled "State Commission"; secondly, at the same time, doing a 'little' downsizing of state institutions; third, efforts to avoid the politicization of recruitment traps by pulling out a number of institutions with political tendencies from the fit and proper test in the DPR to be brought to the DPD room which is a regional representation, not a political representation (Zainal Arifin Mochtar, 2017) Some independent state institutions proposed by the DPD to serve as state commissions regulated in the constitution are:

1. The Judicial Commission, in addition to the supervisory authority over judges, is extended to other legal apparatuses, such as the police and prosecutors. This institution focuses on the administration of justice, recruitment, promotion, transfer, and sanctions.

2. Corruption Eradication Commission, its authority as a deterrent and prosecutor of criminal acts of corruption can be expanded to be able to oversee the agenda of good governance, so that the creation of a government that is free of corruption with prevention and legal action

3. National Commission on Human Rights, merge KPAI and Komnas Perempuan so that the protection divisions of the two institutions are united in one commission only.

4. Indonesian Press Commission, merges the Press Council and KPI to maintain the principle of press freedom (Zainal Arifin Mochtar)

In mid-2006, the regional representative board (DPD) formally proposed a change in 
Article 22D of the 1945 Constitution of the Republic of Indonesia to the leadership of the People's Consultative Assembly (MPR). There are three proposals submitted by the DPD:

1. Proposed changes in paragraph (1), namely the Regional Representative Board holds the power to form laws together with the House of Representatives relating to regional autonomy, central and regional relations, the formation and expansion and merging of regions, management of natural resources and other economic resources as well related to the balance between central and regional finances

2. Proposed changes in paragraph (2), namely the Regional Representative Board shall also discuss and consider the House of Representatives on the draft law relating to tax, education, and religion.

3. Proposed changes in paragraph (3), namely the Regional Representative Board to supervise the implementation of laws concerning: regional autonomy, the formation, division, and merging of regions, management of natural resources and other economic resources, implementation of the state budget of revenue and expenditure, taxes, education and religion as well as conveying the results of their supervision to the House of Representatives and the Government for further action

The three proposals are desired by the
Regional Representative Board (DPD) to approve or reject the draft law relating to regional autonomy; central and regional relations; formation, expansion, and merging of regions; management of natural resources and other economies; as well as the centreregional financial balance which has been approved by the DPR. In addition, the DPD can also reject a bill that has been approved by the DPR and therefore cannot be submitted during the next trial period (Kompas, 2006). The President also has a veto to be able to refuse to ratify a bill approved by the DPR and DPD. However, the draft law rejected by the President is valid if it is approved by at least $2 / 3$ members of the DPR and $2 / 3$ members of the DPD by determining the time limit for adoption (Marwan Mas, 2018)

Jimly Asshiddiqie argues that after the fourth Amendment of the 1945 Constitution of the Republic of Indonesia cannot be said to be a bicameral representation system, this resulted in the authority in the field of legislative DPD not having a role in decision making (Jimly Asshiddiqie, 2010). In line with this opinion, according to Saldi Isra, the limited authority possessed by the DPD in accordance with Article 22D of the 1945 NRI Constitution cannot be said to be a function of legislation, because in legislation theory the legislation function must be seen in its entirety, from the submission to the decision making from draft law to be a law (constitution).

Some of the articles in the 1945 
Constitution of the Republic of Indonesia which are not consistent with the position and authority possessed by the DPD as part of the MPR as stipulated in Article 2 paragraph (1). The inconsistent article is Article 7A relating to the dismissal of the President and Vice President, in the article the DPD is not mentioned as one of the proposers for the dismissal of the President and Vice President, as well as in the formal rules of dismissal of the President and Vice President as stipulated in Article 7B, The DPD also does not have a full role as a member of the MPR, because without the DPD any MPR membership session, which is majority by the DPR, will continue. The same is true of the provisions of Article 7C, that the President cannot dissolve and/or freeze the DPR, in this case, the DPD can be dissolved by the President. Article 9 paragraph (1) and paragraph (2) governing the taking of the oath of the President and Vice President are also not mentioned in that article. This lack of synchronization deviates from the idea of forming a DPD and a bicameral system adopted by Indonesian state administration. Therefore, the idea is essentially to strengthen the integrity of the nation, increase the aggregation and accommodation of aspirations in the context of formulating national policies for the benefit of the regions, and to increase the empowerment of regions and communities (Salmon N.M. Nirahua, 2011)

The difference in understanding and authority possessed by the DPD must be different from the DPR so that the community can differentiate its authority, in addition, to be able to avoid double representation. By continuing to differentiate his authority, Hartati recommends that the DPD have the right to independent initiatives but remain to the authority that already exists in Article 22D. in addition, taking a position to be able to approve or reject any draft law that will be taken a decision. And the last is the imperative to supervise all issues related to regionalism (Hartati, 2018)

Based on the results of this research, all the powers held by the DPD must be strengthened so that there is no imbalance between weak authority and high legitimacy. In addition, it is expected that during the fifth amendment of the 1945 Constitution of the Republic of Indonesia NRI can adopt a strong bicameralism system so that power between legislative institutions can be balanced so that there is no longer an imbalance of authority.

\section{CONCLUSION}

The position of the DPD RI does not have the authority in the legislative function, although it is only limited to submitting and discussing certain draft laws that have been proposed, even in the case of supervision which is limited to supervise the implementation of certain laws and discussing and giving consideration to the results of their supervision to the DPR. The ideal idea to strengthen the DPD RI from experts, as well as 
from the analysis results of the author is carried out the fifth amendment of the 1945 Constitution of the Republic of Indonesia in 1945 , one of which is in terms of its authority to be equal to the authority of the Parliament, which can participate in deciding draft laws related to its authority in accordance with Article 22D of the 1945 Constitution of the Republic of Indonesia. Besides that, the Indonesian legislature can adopt a strong bicameralism, not perfect bicameralism.

\section{REFERENCES}

[1] Asshiddiqie, Jimly. (2006). Konstitusi dan Konstitusionalisme Indonesia, Jakarta: Konstitusi Press.

[2] Asshiddiqie, Jimly. (2009). Pengantar Ilmu Hukum Tata Negara, Edisi I, Cet. V; Depok: Rajawali Pers,

[3] Budiardjo, Miriam. (2013). Dasar-Dasar Ilmu Politik, Edisi Revisi Cet. VI, Jakarta: PT. Gramedia Pustaka Utama,

[4] Dewan Perwakilan Daerah (2014), Peraturan Dewan Perwakilan Daerah Republik Indonesia Nomor 1 Tahun 2014 tentang Tata Tertib.

[5] Hartati, (2018). Menatap Masa Depan Dewan Perwakilan Daerah, Jambi: Trisar Mitra Utama, Jambi,

[6] Isra, Saldi. (2010). Pergeseran Fungsi Legislasi, Menguatnya Legislasi Parlementer dalam Sistem Ketatanegaraan Indonesia, Edisi 1 Cet. 1; Jakarta: Rajawali Pers,

[7] Jurdi, Fajlurrahman. (2019). Hukum Tata Negara Indonesia, Cet. I; Jakarta: Kencana,

[8] Lubis, M. Solly. (1975). Asas-Asas Hukum Tata Negara, Bandung: Penerbit Alumni,

[9] Mas, Marwan. (2018). Hukum Konstitusi dan Kelembagaan Negara, Cet. I; Depok: Rajawali Pers,
[10] Mochtar, Zainal Arifin (2017). Lembaga Negara Independen, Dinamika Perkembangan dan Urgensi Penataannya Kembali Pasca-Amandemen Konstitusi, Depok: Rajawali Pers, Depok,

[11] MPR RI, Badan Pengkajian. (2017). Cheks and Balances dalam Sistem Ketatanegaraan Indonesia, Cet: I, Jakarta: Badan Pengkajian MPR RI,

[12] Nirahua, Salmon N.M. Kedudukan dan Kewenangan Dewan Perwakian Daerah dalam Sistem Ketatanegaraan Indonesia, (Jurnal Hukum Universitas Pattimura: Nomor 4, Volume 18, Oktober 2011), h 593.https://media.neliti.com/media/publicatio ns/84114-ID-kedudukan-dan-kewenangandewan-perwakila.pdf diakses tanggal 28 Oktober 2019, Pukul 23:33 WITA.

[13] Republik Indonesia, (1945). Undang-Undang Dasar Negara Republik Indonesia Tahun

[14] Republik Indonesia, Undang-Undang Nomor 12 Tahun 2011 tentang Pembentukan Peraturan Perundang-Undangan.

[15] Republik Indonesia, Undang-Undang Nomor 2 Tahun 2018 tentang perubahan kedua atas Undang-Undang Nomor 17 Tahun 2014 tentang Majelis Permusyawaratan Rakyat, Dewan Perwakilan Rakyat, Dewan Perwakilan Daerah, Dan Dewan Perwakilan Rakyat Daerah.

[16] Sarja, (2016).Negara Hukum, Teori dan Praktek, Cet. I; Yogyakarta: Penerbit Thafa Media,

[17] Sulardi, (2012). Menuju Sistem Pemerintahan Presidensiil Murni, Malang: Setara Press Kelompok Penerbit In-Trans,

[18] Sulardi, Rekonstruksi Kedudukan DPD dan DPR Menuju Bikameral yang Setara, h. 145. PDF File, diakses 28 Oktober 2019 Pukul 23:43, 